\title{
FAKTOR-FAKTOR YANG BERHUBUNGAN DENGAN PERAN KELUARGA SEBAGAI CAREGIVER PASIEN SKIZOFRENIA
}

\author{
A.A. Istri Dalem Hana Yundari ${ }^{1,} \mathrm{Ni}$ Made Yunita Dewi ${ }^{2}$ \\ 1,2. Program Studi Ilmu Keperawatan, STIKes Wira Medika PPNI Bali ${ }^{1,}$ \\ *Email: hanayundari@gmail.com
}

\begin{abstract}
Abstrak
Peran keluarga sebagai caregiver pasien skizofrenia menjadi hal utama untuk mencegah kekambuhan serta sangat penting untuk keberhasilan terapi pada perawatan pasien skizofrenia. Penelitian ini bertujuan untuk mengetahui faktor-faktor yang berhubungan dengan peran keluarga sebagai caregiver pasien skizofrenia. Metode: Desain penelitian adalah korelasi, dengan pendekatan cross sectional. Teknik sampling dengan cara non probability sampling yaitu purposive sampling, sebanyak 256 orang. Analisa data dengan menggunakan uji Rank Spearman. Hasil: Hasil penelitian didapatkan bahwa ada hubungan antara faktor pengetahuan dan sikap dengan peran keluarga sebagai caregiver pasien skizofrenia $(\mathrm{p}<0,05)$, sedangkan tidak ada hubungan faktor fasilitas kesehatan dengan peran keluarga sebagai caregiver pasien skizofrenia ( $>$ >0,05). Diskusi: Hal ini disebabkan karena pengetahuan dan sikap merupakan faktor predisposisi terbentuknya prilaku yaitu peran keluarga sebagai caregiver. Saran kepada keluarga agar memberikan motivasi dan aktif mengikuti kegiatan-kegiatan yang berhubungan dengan peningkatan pemahaman tentang perawatan pasien dirumah.
\end{abstract}

Kata kunci: Peran keluarga, Caregiver, Pengetahuan, Sikap.

\begin{abstract}
Related Factors with The Role of The Family As Caregiver To Skizofrenia Patients. The role of the family as caregiver of schizophrenic patients is central to preventing recurrence and is essential for success in the treatment of schizophrenic patients. This study aims to determine the factors associated with the role of the family as caregiver schizophrenia patients. Method: The study design is correlation, with cross sectional approach. Sampling technique by nonprobability sampling that is purposive sampling, as many as 256 people. Data analysis use Rank Spearman test. Result: The result showed that there was a correlation between knowledge factor and attitude with family role as caregiver of schizophrenia patient $(p<0,05)$, whereas there was no correlation of health facility factor with family role as caregiver of schizophrenia patient ( $p>0,05)$. Discussion: This is because knowledge and attitudes are predisposing factors in the formation of behaviors, namely the role of the family as caregiver. Suggestions to the family to provide motivation and actively follow the activities related to the improvement of understanding about home patient care.
\end{abstract}

Keywords: Family role, Caregiver, Knowledge, Attitude. 


\section{Pendahuluan}

Perkembangan zaman dan arus globalisasi yang begitu pesat memunculkan berbagai macam fenomena dan permasalahan dalam kehidupan masyarakat, salah satunya masalah kesehatan khususnya masalah gangguan kesehatan jiwa. Pasien gangguan jiwa pada era globalisasi sekarang ini jumlahnya cenderung mengalami peningkatan. Salah satu penyebab bertambahnya pasien gangguan jiwa diperkirakan adalah beban hidup yang semakin berat (Zainudin, 2014).

Berdasarkan data WHO tahun 2015, prevalensi penderita skizofrenia berjumlah 26 juta penderita di seluruh dunia, sedangkan di Indonesia prevalensi penderita skizofrenia sekitar 1-2\% penduduk atau berjumlah 2 - 4 juta jiwa penderita skizofrenia. Hasil Riset Kesehatan Dasar (Riskesdas) tahun 2013 skizofrenia pada penduduk Indonesia 1,7 per mil artinya ada satu sampai dua penduduk dari 1000 penduduk Indonesia menderita skizofrenia. Gangguan jiwa skizofrenia terbanyak di Daerah Istimewa Yogyakarta, Aceh, Sulawesi Selatan, Jawa Tengah dan Bali. Data Riskesdas 2013 menunjukkan prevalensi penderita Skizofrenia di Indonesia adalah 0,3\% sampai 1\%. Hasil Riskesdas 2013 Provinsi Bali berada di peringkat kelima kasus gangguan jiwa skizofrenia terbanyak dengan prevalensi 2,3 per mil (Depkes RI, 2016). Tahun 2016 tercatat sebanyak 9000 orang di Bali mengalami gangguan jiwa berat (Dinkes Provinsi Bali, 2016).

Data penderita gangguan jiwa yang sedang dalam perawatan di keluarga dan sedang menjalani rawat jalan ke Poliklinik Jiwa Rumah sakit Jiwa Provinsi Bali, diperoleh data kunjungan rata-rata 35 sampai 40 orang penderita gangguan jiwa/hari yang sudah melakukan rawat jalan secara rutin atau berulang. Jumlah pasien yang berkunjung pada bulan Oktober 2016 sebanyak 870 orang, sebesar $80 \% \quad$ (696 orang) menderita skizofrenia. Pada bulan Nopember 2016 sebanyak 890 orang yang berkunjung ke poliklinik jiwa, sebanyak 88,7 \% (789 orang) menderita skizofrenia. Sedangkan pada bulan Desember 2016 pasien yang berkunjung ke poliklinik jiwa RSJ Provinsi Bali adalah sebanyak 789 orang, 82\% (646 orang) menderita skizofrenia. Jadi ratarata pasien skizofrenia yang berkunjung ke poliklinik jiwa RSJ Provinsi Bali 
selama tiga bulan trakhir Oktober, Nopember dan Desember tahun 2016 adalah 710 orang. Berdasarkan data catatan rekapitulasi Poliklinik Jiwa Rumah sakit Jiwa Provinsi Bali mencatat dalam tiga bulan terakhir hampir rata 30 40 orang yang sering terlambat atau bahkan tidak datang, minum obat tidak teratur dan sesuai anjuran, sehingga saat datang berobat pasien sudah mengalami kekambuhan yang sudah tidak dapat dikendalikan.

Proses penyembuhan pada pasien gangguan jiwa memerlukan waktu cukup lama sehingga memerlukan kemampuan pasien untuk menjalankan program pengobatan dalam rutinitas sehari-hari. Menurut Herdman (2014) salah satu kriteria hasil yang diharapkan pada perawatan pasien skizofrenia di rumah adalah peran keluarga dalam merawat anggota keluarga dengan skizofrenia khususnya pengelolaan pengobatan pada skizofrenia untuk mencegah kekambuhan. Penatalaksanaan program pengobatan menjadi hal utama karena mempertahankan regimen terapeutik sangat penting untuk keberhasilan terapi pada perawatan gangguan jiwa.

$$
\text { Pengelolaan pengobatan }
$$
merupakan kemampuan untuk mematuhi program terapi yang telah ditentukan baik kualitas maupun kuantitasnya melalui suatu pola pengaturan dan integrasi kedalam keluarga yang memproses program untuk pengobatan penyakit atau gejala sisa dari penyakit yang tidak memuaskan untuk memenuhi tujuan kesehatan yang spesifik (Herdman, 2014).

Keberhasilan program pengobatan tidak hanya terletak pada terapi obat psikofarmaka dan jenis terapi lainnya, tetapi juga peran serta keluarga dan masyarakat turut menentukan (Stuart, 2016). Keluarga perlu memperlakukan penderita gangguan jiwa dengan sikap yang bisa membubuhkan dan mendukung tumbuhnya harapan yang optimisme. Harapan dan optimisme akan menjadi motor penggerak pemulihan dari penderita gangguan jiwa, di lain pihak kata menghina dan memandang rendah bersifat melemahkan proses pemulihan. Peran keluarga merupakan salah satu faktor penting dalam pemulihan penderita gangguan jiwa (Setiadi,2014). Pengelolaan pengobatan harus ditekankan menjadi suatu kebutuhan bagi pasien supaya lebih optimal kembali ke keluarga dan masyarakat sehingga peran keluarga sangat penting agar pasien skizofrenia tidak lagi dirawat inap untuk periode waktu yang lama, sehingga 
pasien dapat hidup bersama anggota keluarga secara mandiri serta tidak menjadi beban yang sangat memberatkan lagi (Yosep, 2014).

Kemampuan keluarga memberikan perawatan kepada anggota keluarganya dipengaruhi oleh berbagai faktor. Berdasarkan teori Lawrence Green dalam buku Lestari (2015), faktor-faktor yang mempengaruhi perilaku kesehatan meliput: Predisposing factor (faktor predisposisi) meliputi pengetahuan dan sikap masyarakat terhadap kesehatan, kepercayaan dan tradisi masyarakat terhadap hal-hal yang berkaitan dengan kesehatan, sistem nilai yang dianut masyarakat, Enabling faktor (faktor pemungkin) yaitu meliputi tersedianya fasilitas kesehatan bagi masyarakat termasuk rumah sakit, puskesmas, poliklinik, posyandu, posbindu, pos obat desa, dokter atau bidan praktek swasta.

Penelitian yang dilakukan oleh Edi (2016), yang berjudul "peran petugas kesehatan dan pengetahuan keluarga terhadap peningkatan kemampuan merawat klien gangguan jiwa di rumah", penelitian ini adalah penelitian deskritif korelasi dengan pendekatan cross sectional. Hasil Penelitian ini menunjukkan bahwa ada hubungan peranan petugas kesehatan dengan peningkatan kemampuan merawat klien gangguan jiwa di rumah dengan nilai $p=$ 0,008 dan pengetahuan keluarga dengan peningkatan kemampuan merawat klien gangguan jiwa di rumah dengan nilai $\mathrm{p}=$ 0,005. Penelitian tentang peranan keluarga juga dilakukan oleh Nur Afiyati (2015) dengan judul "Hubungan tingkat pendidikan dan peranan keluarga terhadap kepatuhan berobat pasien skizofrenia di Poli Jiwa RSUD Kraton Kabupaten Pekalongan". Penelitian ini adalah penelitian deskritif korelasi dengan pendekatan cross sectional. Hasil Penelitian ini menunjukkan bahwa ada hubungan peranan keluarga terhadap kepatuhan berobat pasien skizofrenia $(\mathrm{p}=0,002<0,05)$.

Hasil studi pendahuluan di Poliklinik Jiwa Rumah Sakit Jiwa Provinsi Bali, yang dilakukan dengan melakukan wawancara dengan 10 orang keluarga pasien sizofrenia, mayoritas keluarga pasien yaitu sebanyak 7 orang, peran keluarga dalam merawat pasien skizofrenia mendapatkan skor "kecil" yaitu mendapat nilai antara $0-7$, keluarga mengatakan bisa merawat dan mengawasi pasien minum obat meskipun kadang terlambat saat mengantar pasien kontrol. 
Berdasarkan hal tersebut peneliti tertarik untuk mengadakan penelitian tentang faktor-faktor yang berhubungan

\section{Metode}

Penelitian ini merupakan penelitian deskritif korelasional dengan rancangan cross sectional. Populasi pada penelitian ini adalah semua keluarga pasien skizofrenia di Poliklinik Jiwa RSJ Provinsi Bali, yaitu sebanyak 256 orang Waktu pelaksanaan pengambilan data pada penelitian ini telah dilaksanakan dengan peran keluarga sebagai caregiver pada pasien skizofrenia di Poliklinik Jiwa RSJ Provinsi Bali.

April sampai dengan Mei 2017. Teknik sampling yang digunakan pada penelitian ini dilakukan dengan cara non probability sampling yaitu purposive sampling. Untuk menganalisa hubungan antara dua variabel digunakan uji statistik Sperman Rho.

\section{Hasil}

Analisis bivariat untuk fasilitas kesehatan dengan peran keluarga menganalisa hubungan antar dua variabel, yaitu untuk menganalisa hubungan pengetahuan, sikap dan berikut ini

Tabel 1: Hubungan Pengetahuan Dengan Peran Keluarga Sebagai Caregiver Pasien Skizofrenia

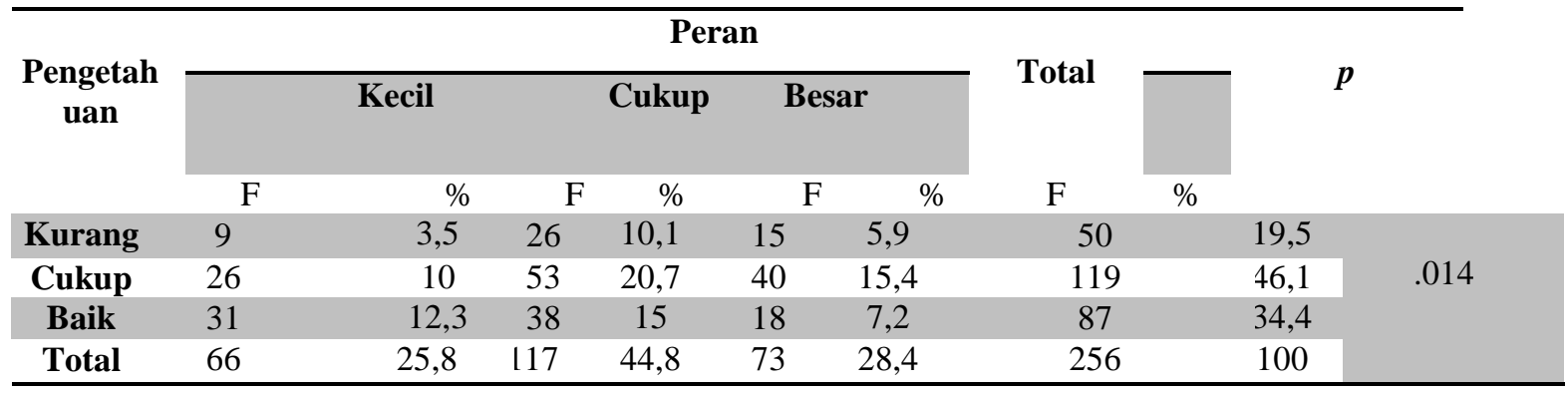

Berdasarkan tabel 1 diatas dapat diketahui sebagian besar responden memiliki pengetahuan cukup dan peran yang cukup yaitu sebanyak 53 orang $(20,7 \%)$. Berdasarkan uji spearman rho untuk menganalisa faktor pengetahuan keluarga dengan peran keluarga sebagai caregiver pasien skizofrenia didapatkan nilai $\mathrm{p}=0,014$. 
Yundari, I.D.H., \& Dewi, N.M.Y, Faktor-Faktor Yang Berhubungan Dengan Peran Keluarga Sebagai Caregiver Pasien Skizofrenia.

Tabel 2: Hubungan Sikap Dengan Peran Keluarga Sebagai Caregiver Pasien Skizofrenia

\begin{tabular}{|c|c|c|c|c|c|c|c|c|c|}
\hline \multirow{3}{*}{ Sikap } & & & & \multicolumn{6}{|c|}{ To1 } \\
\hline & \multicolumn{2}{|c|}{ Kecil } & \multicolumn{2}{|c|}{ Cukup } & \multicolumn{2}{|c|}{ Besar } & \multirow{2}{*}{$\begin{array}{r}\text { Peran } \\
\text { F }\end{array}$} & \multirow{2}{*}{$\begin{array}{r}\text { Total } \\
\%\end{array}$} & \multirow[t]{2}{*}{$p$} \\
\hline & $\mathrm{F}$ & $\%$ & $\mathrm{~F}$ & $\%$ & $\mathrm{~F}$ & $\%$ & & & \\
\hline Buruk & 8 & 3,1 & 17 & 6,6 & 8 & 3,1 & 33 & 12,8 & \multirow{5}{*}{.007} \\
\hline Kurang & & 6,2 & 34 & 13,3 & 23 & 9,0 & 73 & 28,6 & \\
\hline Cukup & 23 & 8,9 & 43 & 16,9 & 26 & 10,2 & 92 & 36 & \\
\hline Baik & 19 & 7,4 & 23 & 8,9 & 16 & 6,3 & 58 & 22,6 & \\
\hline Total & 66 & 25,7 & 117 & 45,7 & 73 & 28,5 & 256 & 100 & \\
\hline
\end{tabular}

Berdasarkan tabel 2 diatas dapat menganalisa faktor sikap keluarga diketahui sebagian besar responden dengan peran keluarga sebagai caregiver memiliki sikap cukup dan peran yang pasien skizofrenia didapatkan nilai cukup yaitu sebanyak 43 orang $(16,9 \%) . \quad \mathrm{p}=0,007$.

Berdasarkan uji spearman rho untuk

Tabel 3: Hubungan Fasilitas Kesehatan Dengan Peran Keluarga Sebagai Caregiver Pasien Skizofrenia

\begin{tabular}{|c|c|c|c|c|c|c|c|c|c|}
\hline \multirow{3}{*}{$\begin{array}{l}\text { Fasilitas } \\
\text { Kesehatan }\end{array}$} & \multicolumn{6}{|c|}{ Peran } & \multirow[b]{2}{*}{$\begin{array}{l}\text { To } \\
\text { tal }\end{array}$} & & \multirow{3}{*}{$p$} \\
\hline & \multicolumn{2}{|c|}{ Kecil } & \multicolumn{2}{|c|}{ Cukup } & \multicolumn{2}{|c|}{ Besar } & & & \\
\hline & $\mathrm{F}$ & $\%$ & $\mathrm{~F}$ & $\%$ & F & $\%$ & $\mathrm{~F}$ & $\%$ & \\
\hline Kurang & 7 & 2,7 & 21 & 8,2 & 9 & 3,9 & 37 & 14,8 & \\
\hline Cukup & 29 & 11,3 & 57 & 22,3 & 40 & 15,4 & 126 & 49,0 & .208 \\
\hline Baik & 30 & 11,7 & 39 & 15,2 & 24 & 9,3 & 93 & 36,2 & \\
\hline Total & 66 & 25,7 & 117 & 45,7 & 73 & 28,6 & 256 & 100 & \\
\hline
\end{tabular}

Berdasarkan tabel 3 diatas dapat diketahui sebagian besar responden memiliki fasilitas cukup dengan peran yang cukup yaitu sebanyak 57 orang $(22,3 \%)$. Berdasarkan uji spearman rho

\section{Pembahasan}

\section{Hubungan Pengetahuan Dengan Peran \\ Keluarga Sebagai Caregiver Pasien Skizofrenia}

untuk menganalisa faktor fasilitas kesehatan dengan peran keluarga sebagai caregiver pasien skizofrenia didapatkan nilai $\mathrm{p}=0,208$.
Pengetahuan adalah hasil penginderaan manusia, atau hasil tahu seseorang terhadap objek melalui indera yang dimilikinya (mata, hidung, telinga, 
dan sebagainya). Dengan sendirinya, pada waktu penginderaan sampai menghasilkan pengetahuan tersebut sangat dipengaruhi intensitas perhatian dan persepsi terhadap objek. Sebagian besar pengetahuan seseorang diperoleh melalui indera pendengaran (telinga), dan indera penglihatan (Notoatmodjo, 2014). Faktor-faktor yang mempengaruhi pengetahuan, meliputi faktor internal dan ekternal. Faktor internal terdiri dari pendidikan, pekerjaan dan umur, sedangkan faktor eksternal meliputifaktor lingkungan dan sosial budaya (Wawan dan Dewi, 2010). Pengetahuan seseorang tentang suatu objek mengandung dua aspek, yaitu aspek positif dan negatif. Kedua aspek ini yang akan menentukan sikap seseorang semakin banyak aspek positif dan objek yang diketahui, maka akan menimbulkan sikap makin positif terhadap objek tertentu (Dewi dan Wawan, 2010).

Hasil penelitian ini didukung oleh penelitian yang dilakukan oleh Nur Afiyati (2015) dengan judul "Hubungan tingkat pengetahuan dan peranan keluarga terhadap kepatuhan berobat pasien skizofrenia di Poli Jiwa RSUD Kraton Kabupaten Pekalongan”. Penelitian ini adalah penelitian deskritifkorelasi dengan pendekatan cross sectional. Hasil Penelitian ini menunjukkan bahwa ada hubungan peranan keluarga terhadap kepatuhan berobat pasien skizofrenia $(p=0,002$ $<0,05)$. Hasil penelitian yang didapat sama dengan penelitian yang dilakukan oleh Nur Afiyati (2015) dikarenakan responden sama-sama sudah mendapatkan informasi tentang perawatan pasien skizofrenia tetapi pemahaman yang kurang dikarenakan faktor eksternal yang mempengaruhi penerimaan informasi.

Berdasarkan hal ini maka pengetahuan masyarakat tentang perawatan pasien skizofrenia di rumah sangat penting agar dapat mempraktikkan cara perawatan anggota keluarga dengan skizofrenia untuk mencegah kekambuhan. Hasil penelitian yang menunjukkan sebagian besar pengetahuan responden tentang perawatan pasien skizofrenia dikategorikan cukup, hal ini dikarenakan didukung oleh tingkat pendidikan masyarakat yang sebagian besar lulusan SMP, dimana dalam pemberian pendidikan kesehatan memerlukan cara lebih dimengerti sehingga lebih memahami informasi yang diberikan oleh petugas kesehatan. Selain itu bisa disebabkan kurang informasi yang 
diterima oleh masyarakat tentang perawatan pasien skizofrenia, sedangkan pada penelitian pada tingkat pendidikan dasar dengan tingkat pengetahuan dikategorikan cukup dikarenakan masyarakat telah mendapatkan informasi secara informal dari media massa dan media elektronik.

Faktor umur dan pekerjaan juga memegang peranan penting dalam menentukan tingkat pengetahuan seseorang (Wawan dan Dewi, 2010). Jumlah responden yang sebagian besar berumur 31-40 tahun sebanyak 124 orang $(48,4 \%)$ menunjukkan semakin cukup umur seseorang maka kematangan pola berpikir seseorang semakin matang yang diperoleh dari pendidikan maupun pengalaman sehari-hari. Jumlah responden yang mayoritas bekerja di sektor informal (swasta) sebanyak 96 orang $(37,5 \%)$ juga memepengaruhi pengetahuan seseorang karena bekerja di sektor informal tidak harus memiliki pendidikan yang tinggi sehingga mereka hanya mendapatkan pengetahuan dari lingkungan hidup sehari-hari. Berbeda dengan bekerja di bidang sektor formal yang membutuhkan pendidikan tinggi sehingga sejalan dengan semakin luasnya pengetahuan seseorang. Namun tingkat pedidikan yang tinggi dan pekerjaan yang bagus / kantoran tidak menjamin seseorang memiliki pengetahuan yang baik, karena dari hasil penelitian ini masih ada beberapa responden yang memiliki tingkat pendidikan tinggi dan pekerjaanyang bagus memiliki pengetahuan yang buruk. Hal tersebut diakibatkan oleh kurangnya pemahaman tentang perawatan anggota keluarga dengan skizofrenia.

Sikap merupakan reaksi atau respon yang masih tertutup dari seseorang terhadap suatu stimulus atau objek. Sikap ini merupakan kesiapan atau kesedian untuk bertindak, dan bukan merupakan pelaksanaan motif tertentu. Sikap belum merupakan suatu perilaku. Sikap itu masih merupakan reaksi tertutup, bukan merupakan kesiapan untuk bereaksi terhadap objek di lingkungan tertentu sebagai suatu penghayatan terhadap objek (Notoatmodjo, 2014).

Faktor-faktor yang mempengaruhi sikap (Wawan dan Dewi, 2010) antara lain: Pengalaman pribadi; yaitu untuk dapat menjadi dasar pembentukan sikap, pengalaman pribadi haruslah meninggalkan kesan yang kuat. Sikap akan lebih mudah terbentuk apabila pengalaman pribadi tersebut terjadi dalam situasi yang melibatkan faktor 
emosional. Pengaruh orang lain yang dianggap penting; yaitu pada umumnya individu cenderung untuk memiliki sikap yang konformis atau searah dengan sikap orang yang dianggap penting. Kecenderungan ini antara lain dimotivasi oleh keinginan untuk berafiliasi dan keinginan untuk menghindari konflik dengan orang yang dianggap penting tersebut. Pengaruh kebudayaan; yaitu tanpa disadari kebudayaan telah menanamkan garis pengarah sikap kita terhadap berbagai masalah.

Penelitian yang sama dilakukan oleh Sri Wulansih (2008) dengan judul "Hubungan antara tingkat pengetahuan dan sikap keluarga dengan kekambuhan pada pasien skizofrenia di RSJD Surakarta" hasil penelitian menunjukkan ada hubungan antara sikap keluarga dengan kekambuhan pasien skizofrenia. Hasil penelitian ini didapatkan bahwa keluarga bersikap baik yaitu 50\% (25 responden), sedangkan keluarga yang bersikap cukup sebanyak 35,9 \% (92 responden) artinya keluarga cukup dalam memberikan perawatan kepada anggota keluarga yang mengalami skizofrenia.

\section{Hubungan Sikap Dengan Peran Keluarga Sebagai Caregiver Pasien Skizofrenia}

Berdasarkan hasil penelitian ini maka sikap yang cukup tentang perawatan pasien skizofrenia karena pada usia responden sebagian besar telah berusia lebih dari 40 tahun, semakin cukup umur seseorang maka kematangan seseorang dalam berpikir semakin matang dan semakin bertambahnya umur seseorang maka kematangan akal seseorang juga akan semakin kuat sehingga menumbuhkan sikap yang semakin baik pada diri seseorang. Bertambahnya umur juga menyebabkan pengalaman seseorang semakin luas sehingga menjadi dasar pembentukan dalam bersikap, dimana pada usia lebih dari 40 tahun tersebut adalah usia matang sehingga lebih menimbulkan reaksi yang positif, disamping itu bisa karena keluargamempunyai anggota keluarganya yang skizofrenia sehingga sikapnya lebih baik terhadap perawatan pasien skizofrenia.

Faktor pendidikan juga memegang peranan penting terhadap sikap seseorang. Pendidikan adalah proses perubahan sikap dan tingkah laku seseorang dan juga usaha mendewasakan seseorang melalui upaya pengajaran dan 
pelatihan baik disekolah ataupun di luar sekolah. Pendidikan juga merupakan salah satu factor yang mempengaruhi persepsi seseorang karena dapat membuat seseorang untuk lebih mudah mengambil keputusan. Jumlah responden yang sebagian besar lulusan SMP yaitu sebanyak 85 orang $(33,2 \%)$ diharapkan mampu memberikan perawatan yang maksimal terhadap anggota keluarga yang mengalami gangguan skizofrenia. Dalam penelitian ini tidak dipungkiri dari hasil penelitian masih ditemukan beberapa responden yang meniliki tingkat pendidikan tinggi namun memiliki sikap yang buruk terhadap perawatan pasien skizofrenia akibat dari pemahaman yang kurang tentang perawatan pasien dengan skizofrenia sehingga mampu mempengaruhi sikap keluarga terhadap perawatan pasien skizofrenia.

Peran yang didasari oleh pengetahuan akan lebih lama dari pada yang tidak didasari oleh pengetahuan. Pengetahuan seseorang sangat berpengaruh dalam peran keluarga sebagai caregiver karena pengetahuan merupakan hasil tahu dan ini terjadi setelah seseorang melakukan penginderaan terhadap suatu objek tertentu (Notoatmodjo, 2014). Caregiver sebagai seseorang dalam keluarga, baik itu orang tua angkat, atau anggota keluarga lain yang membantu memenuhi kebutuhan anggota keluarga yang mengalami ketergantungan. Caregiver keluarga didefinisikan sebagai individu yang memberikan perawatan berkelanjutan secara bersungguhsungguh setiap hari dan dalam waktu periode yang lama bagi anggota keluarganya yang mengalami penyakit kronis (Stuart,2016).

Hasil penelitian ini juga didukung oleh penelitian yang dilakukan oleh Kiky.A (2015) dengan judul "Hubungan pengetahuan dan sikap dengan motivasi keluarga dalam memberikan dukungan pada keluarga gangguan jiwa". Dari hasil penelitian ini dapat disimpulkan bahwa pengetahuan seseorang dalam memberikan dukungan terhadap pasien gangguan jiwa merupakan langkah awal menentukan peran keluarga terutama dalam hal memotivasi pasien untuk sembuh dengan cepat. Hal ini sejalan dengan hasil penelitian Ajeng A.P (2015) yang berjudul “ Hubungan Pengetahuan dan Sikap tentang Gangguan Jiwa dengan Dukungan Keluarga dalam Pengobatan Pasien Skizofrenia di RSJ Propinsi Lampung “ menunjukkansemakin kurang tingkat pengetahuan dalam memberikan 
dukungan terhadap pasien gangguan jiwa maka akan membuat semakin kecil peran keluarga dalam merawat anggota keluarga yang mengalami gangguan jiwa, begitupula sebaliknya tingginya pengetahuan dalam memberikan dukungan terhadap pasien dengan gangguan jiwa maka akan membuat semakin besar peran keluarga dalam merawat anggota keluarga yang mengalami gangguan jiwa.

Berdasarkan hasil penelitian ini makapengetahuan yang dimiliki oleh keluarga menjadi pijakan keluarga dalam upaya merawat anggota keluarga yang mengalami skizofrenia. Pengetahuan sangat mempengaruhi peran keluarga dalam bertindak, pengetahuan yang baik tentang cara perawatan anggota keluarga dengan skizofrenia akan menimbulkan peran yang baik seperti memberikan dukungan emosional keluarga dalam hal memotivasi pasien untuk sembuh ataupun menumbuhkan harapan dan optimisme, pengawasan minum obat serta upaya pencegahan kekambuhan anggota keluarga yang mengalami skizofrenia.

Faktor-faktor menyebabkan seseorang berperan ada enam alasan, yaitu pengetahuan, kepercayaan, sikap, orang penting sebagai refensi, sumber daya dan kebudayaan. Peran keluarga dalam perawatan pasien skizofrenia ini diwujudkan dengan cara meningkatkan fungsi afektif yang dilakukan dengan memotivasi, menjadi pendengar yang baik, membuat senang, memberi kesempatan rekreasi, memberi tanggung jawab dan kewajiban peran dari keluarga sebagai pemberi asuhan (Stuart, 2016).

Keluarga perlu memperlakukan penderita gangguan jiwa dengan sikap yang bisa menumbuhkan dan mendukung tumbuhnya harapan dan optimisme. Harapan merupakan pendorong proses pemulihan, salah satu faktor penting dalam pemulihan adalah adanya keluarga, saudara dan teman yang percaya bahwa seseorang penderita gangguan jiwa bisa pulih dan kembali produktif di masyarakat. Harapan dan optimisme akan menjadi motor penggerak pemulihan dari gangguan jiwa. Dilain pihak, kata- kata yang menghina, memandang rendah, dan menumbuhkan pesimisme akan bersifat melemahkan proses pemulihan (Stuart, 2016).

Peran keluarga diharapkan dalam perawatan penderita gangguan jiwa adalah dalam pemberian obat, pengawasan minum obat dan meminimalkan ekspresi keluarga. Keluarga merupakan unit paling dekat 
Yundari, I.D.H., \& Dewi, N.M.Y, Faktor-Faktor Yang Berhubungan Dengan Peran Keluarga Sebagai Caregiver Pasien Skizofrenia.

dengan penderita dan merupakan "perawat utama" bagi penderita gangguan jiwa. Keluarga berperan dalam cara atau perawatan yang diperlukan penderita gangguan jiwa. Keberhasilan perawat di rumah sakit akan sia-sia jika kemudian mengakibatkan penderita gangguan jiwa harus dirawat kembali di rumah sakit (Stuart, 2016).

Hasil penelitian yang didapat didukung oleh penelitian yang dilakukan oleh Nur Afiyati (2015) dengan judul "Hubungan tingkat pendidikan dan peranan keluarga terhadap kepatuhan berobat pasien skizofrenia di Poli Jiwa RSUD Kraton Kabupaten Pekalongan". Hasil Penelitian ini menunjukkan bahwa ada hubungan peranan keluarga terhadap kepatuhan berobat pasien skizofrenia $(p=0,002<0,05)$. Hal ini juga di dukung oleh penelitian Sri Wulansih (2008) dengan judul " Hubungan antara pengetahuan dan sikap keluarga dengan kekambuhan pada pasien skizofrenia" . Hasil analisa menunjukkan sikap keluarga mempunyai hubungan yang signifikan untuk mencegah kekambuhan pada pasien skizofrenia. Sikap keluarga dalam hal ini adalah afek atau penilaian positif atau negatif terhadap suatu obyek sebagai upaya untuk memperbaiki sikap keluarga dalam memberikan dukungan atau merawat pasienskizofrenia. Penelitian yang sama juga dikemukakan oleh Kiky A (2015) yang berjudul "Hubungan Pengetahuan dan Sikap dengan Motivasi Keluarga dalam Memberikan Dukungan pada Keluarga Gangguan Jiwa " dimana dalam hal ini apabila keluarga memiliki sikap menerima (bersedia memperhatikan stimulus) kemudian merespon terhadap apa yang diketahui tentang pentingnya memberikan dukungan positif secara terus menerus maka keluarga dalam berperan memberikan dukungan terhadap pasien gangguan jiwa kecil bisa menjadi cukup bahkan besar.

Berdasarkan hasil penelitian ini maka sikap yang baik akan lebih memberikan hasil yang baik jika diikuti dengan tindakan yang nyata, dimana sikap yang menerima terhadap keberadaan pasien yang disebabkan oleh pemahaman keluarga terhadap kondisi pasien membuat keluarga lebih peduli dan memberikan dukungan kepada pasien sehingga mampu membantu proses penyembuhan anggota keluarga yang mengalami skizofrenia.

\section{Hubungan Fasilitas Kesehatan Dengan Peran Keluarga Sebagai Caregiver \\ Berdasarkan hasil penelitian didapatkan bahwa fasilitas kesehatan}


yang mendukung perawatan pasien skizofrenia dari 256 orang responden mengatakanfasilitas kesehatan yang mendukungsebagian besar dikategorikan cukup, yaitu sebanyak 126 orang $(49,2 \%)$. Hal ini menunjukkan bahwa sebagian besar tanggapan keluarga tentang fasilitas kesehatantentang perawatan pasien skizofrenia dikategorikan cukup.

Hasil penelitian didapat didukung oleh penelitian Magan (2013) yang berjudul "Hubungan Sarana Prasarana Puskesmas dengan Pemanfaatan Pelayanan Pencegahan Kesehatan di Puskesmas Makale "menyatakan bahwa dari 308 orang responden, sebanyak 257 orang $(83,4 \%)$ yang menilai sarana prasarana pelayanan puskesmas kategori cukup dan sebanyak 51 orang $(16,6 \%)$ yang menilai kurang sarana prasarana pelayanan puskesmas. Hasil penelitian yang didapatkan sama dengan penelitian Magan (2013) dikarenakan fasilitas puskemas hampir sama dalam upaya perawatan pasien skizofrenia untuk mencegah kekambuhan.

Berdasarkan hasil penelitian ini maka fasilitas puskesmas sebagai faktor pemungkin akan membantu masyarakat dalam melakukan upaya perawatan pasien skizofrenia di rumah. Tanggapan dari keluarga atau masyarakat yang menyatakan bahwa sebagian besar fasilitas puskemas yang dikategorikan cukup perlu lebih ditingkatkan agar masyarakat lebih dapat memanfaat fasilitas di puskesmas. Hasil penelitian yang menunjukkan sebagian besar responden menilai fasilitas puskesmas dikategorikan cukup, dikarenakan keluarga belum semuanya memanfaatkan fasilitas yang ada dipuskesmas oleh karena tidak semua masyarakat datang ke puskesmas bila ada masalah dengan kesehatannya.

Berdasarkan hasil uji spearman rho didapatkan bahwa hubungan pengetahuan dengan peran keluarga sebagai caregiver pasien skizofreniadidapatkan nilai $\mathrm{p}=0,014$ yang berarti $\mathrm{H} 0$ ditolak dan Ha diterima, jadi ada hubungan pengetahuan dengan peran keluarga sebagai caregiver pasien skizofrenia.

Puskesmas merupakan organisasi yang bergerak di bidang pelayanan jasa kesehatan yang mempunyai tujuan untuk meningkatkan mutu sumber daya manusia, usia harapan hidup, kesejahteraan keluarga dan masyarakat, serta mempertinggi derajat kesehatan masyarakat akan pentingnya hidup sehat. Fasilitas pelayanan puskesmas harus 
dapat memberikan pelayanan yang berkualitas sesuai dengan standard yang ditetapkan dan dapat menjangkau seluruh lapisan masyarakat (Magan, 2013).

Hasil penelitian berbeda didapatkan oleh Magan (2013)yang berjudul “ Hubungan Sarana Prasarana Puskesmas dengan Pemanfaatan Pelayanan Pencegahan Kesehatan di Puskesmas Makale "mengungkapkan bahwa ada hubungan sarana prasarana puskesmas dengan pemanfaatan pelayanan pencegahan kesehatan di Puskesmas Makale, Kecamatan Makale ( $\mathrm{p}=0,010)$.Hasil penelitian yang didapatkan berbeda dengan penelitian Magan (2013) dikarenakan berbedanya tanggapan masyarakat terhadap fasilitas puskesmas terhadap perubahan peran keluarga.

Pada penelitian ini pada faktor fasilitas kesehatan hamper sebagian besar puskesmas maupun rumah sakit umum menyediakan sarana atau fasilitas kesehatan yang lengkap, baik dari segi obat, tenaga kesehatan khusus jiwa, leaflet atau brosur tentang perawatan pasien gangguan jiwa, ataupun penyuluhan tentang kesehatan jiwa. Sehingga dari hal tersebut menyebabkan peran keluarga kecil akibat dari keluarga tidak memerlukan usaha yang keras untuk memproleh pelayanan kesehatan bagi anggota keluarga yang mengalami gangguan skizofrenia. Berdasarkan hasil penelitian ini maka fasilitas kesehatan yang lengkap tidak menjamin peran keluarga yang besar karena factor kelengkapan dan fasilitas yang ada di puskesmas atau rumah sakit umum maupun fasilitas pelayanan kesehatan lainnya yang menyebabkan keluarga tidak memerlukan usaha yang besar dalam memperoleh pelayanan kesehatan jiwa, akibatnya peran keluarga kecil sebagai caregiver pasien dengan skizofrenia.

\section{Kesimpulan}

Ada hubungan faktor pengetahuan dengan dan faktor sikap dengan peran keluarga sebagai caregiver pasien skizofrenia. Faktor fasilitas kesehatan dengan peran keluarga sebagai caregiver tidak berhubungan.

\section{Saran}

Meningkatkan pemberdayaan keluarga dengan cara membimbing melalui penyuluhan keluarga sehingga mampu memberikan dukungan dan melakukan perawatan pasien di rumah, dan melakukan kunjungan rumah (home visit) kepada keluarga untuk menangani 
penderita skizofrenia. Diharapkan untuk aktif mengikuti kegiatan-kegiatan yang berhubungan dengan peningkatan pemahaman tentang perawatan pasien dirumah seperti mengikuti penyuluhanpenyuluhan yang dilaksanakan oleh Puskesmas atau Rumah Sakit Jiwa agar memahami kondisi pasien sehingga mampu memberikan dukungan dalam perawatan pasien skizofrenia.

\section{Referensi}

Ajeng, A.P., 2015. Hubungan Pengetahuan dan Sikap tentang Gangguan Jiwa dengan Dukungan Keluarga dalam Pengobatan Pasien Skizofrenia di RSJ Propinsi Lampung (online), (diakses 14 Juni 2015).

Aswin, 2010. Skizofrenia Memahami Dinamika Keluarga Pasien. Bandung: Refika Aditama

Arif, 2015. Hubungan Peran Keluarga dengan Kekambuhan Pasien Skizofrenia di Wilayah Kerja UPT Puskesmas Cawas I Klaten. (online),(http://repository.usu.ac.i d/handle/123456789/27919, diakses 17 Januari 2017).

Afiyati, Nur, 2015. Hubungan tingkat pendidikan dan peranan keluarga terhadap kepatuhan berobat pasien skizofrenia di Poli Jiwa RSUD Kraton Kabupaten Pekalongan". (online), (diakses 23 Januari 2017).

Depkes, 2013. Riset Kesehatan Dasar. Jakarta: Badan Penelitian dan Pengembangan Kesehatan Kementerian Kesehatan RI

Dinkes Provinsi Bali, 2014. Profil Kesehatan Provinsi Bali Tahun 2014. Denpasar: Dinas Kesehatan Provinsi Bali
Direja, Ade H.S., 2011. Buku Ajar Asuhan Keperawatan Jiwa. Yogyakarta : Nuha Medika

Edi, 2016. Peran petugas kesehatan dan pengetahuan keluarga terhadap peningkatan kemampuan merawat klien gangguan jiwa di rumah, (online), (diakses 17 Januari 2017).

Fredman, Marilyn M., 2010. Buku Ajar Keperawatan Keluarga: Riset, Teori dan Praktek. Jakarta: EGC

Herdman, 2012. International Nursing Diagnoses: Definitions and Classification 2012-2014. Oxford: Wiley-Blackwell

Keliat, B.A., 2010, Peran Serta Keluarga Dalam Perawatan Klien Gangguan Jiwa. Jakarta: EGC

Kiky,A N. 2015. Hubungan Pengetahuan dan Sikap dengan Motivasi Keluarga dalam Memberikan Dukungan pada Keluarga Gangguan Jiwa. (online). Diakses 14 Juni 2017

Lestari, T., 2015. Kumpulan Teori Untuk Kajian Pustaka Penelitian Kesehatan. Yogyakarta: Nuha Medika.

Magan, 2013. Hubungan Sarana Prasarana Puskesmas dengan Pemanfaatan Pelayanan Pencegahan Kesehatan di Puskesmas Makale . (online), (http://repgsitory.usu.ac.id/handle /123456789/27919, diakses 26 Pebruari 2017).

Maramis, W. F., 2009. Catatan Ilmu Kedokteran Jiwa, Edisi Revisi, Surabaya; Airlangga University Press.

Notoatmodjo, S., 2014. Ilmu Perilaku Kesehatan. Jakarta: Rineka Cipta

Padila, 2012. Keperawatan Keluarga. Yogyakarta: Penerbit Nuha Medika 
Prabowo, Eko, 2014. Buku Ajar Keperawatan Jiwa. Yogyakarta: Nuha Medika

Purnomo, Edi, 2016. Peran Petugas dan Pengetahuan Keluarga Terhadap Peningkatan Kemampuan Merawat Klien Gangguan Jiwa. (online), (http://repository.usu.ac.id/handle /123456789/27919, diakses 28 Januari 2017).

Rasmun, dkk., 2013. Faktor-Faktor Penyebab Kekambuhan Pada Pasien Skizofrenia. Jurnal Husada Mahakam.Volume III No. 5, Mei 2013

Rekam Medik Rumah Sakit Jiwa

Propinsi Bali, 2016. Laporan

Tahunan Rumah Sakit Jiwa

Propinsi Bali. Bangli.

Suryani, L. K. 2011. Skizofrenia. (online). (www.gatra. com/Diakses Tanggal: 20 Januari 2017).

Stuart, Gail. W. 2016. Keperawatan Kesehatan Jiwa. Buku 1. Jakarta: EGC

WHO., 2015. Kesehatan Jiwa, (online). (www. mediaindonesia. Com / 3 Januari 2017).

Wawan, A dan Dewi, M. 2010. Teori dan Pengukuran Pengetahuan, Sikap dan Perilaku Manusia. Yogyakarta: Nuha Medika.

Wulansih, Sri, 2015. Hubungan Antara Tingkat Pengetahuan dan Sikap Keluarga dengan Kekambuhan pada Pasien Skizofrenia. (online), (diakses 14 Juni 2017). 